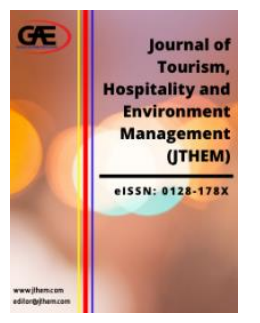

\title{
THE IMPACT OF SWIFTLET FARMING HOUSE ON LOCAL COMMUNITIES
}

\author{
Azlina Md. Yassin ${ }^{1}$, Haidaliza Masram², Haryati Shafii ${ }^{3}$, Mohd Yamani Yahya ${ }^{4}$, Sharifah Meryam \\ Shareh Musa ${ }^{5}$
}

1 Faculty of Technology Management \& Business, Universiti Tun Hussein Onn Malaysia Email: azlina@uthm.edu.my

2 Faculty of Technology Management \& Business, Universiti Tun Hussein Onn Malaysia Email: haidaliza@uthm.edu.my

3 Faculty of Technology Management \& Business, Universiti Tun Hussein Onn Malaysia Email: haryati@uthm.edu.my

$4 \quad$ Faculty of Technology Management \& Business, Universiti Tun Hussein Onn Malaysia Email: yamani@uthm.edu.my

$5 \quad$ Faculty of Technology Management \& Business, Universiti Tun Hussein Onn Malaysia Email: meryam@uthm.edu.my

\section{Article Info:}

\section{Article history:}

Received date: 12.01 .2020

Revised date: 04.02.2020

Accepted date: 04.03.2020

Published date: 15.03.2020

\section{To cite this document:}

Md. Yassin, A., Masram, H., Shafii, H., Yahya, M. Y., Musa, S. M. S. (2020). The Impacts of Swiftlet Farming House in Local Communities. Journal of Tourism, Hospitality and Environment Management, 5 (18), 108-121.

DOI: $10.35631 /$ JTHEM.5180010.

\begin{abstract}
:
Swiftlet farming is an agriculture activity in both commercial building and agriculture land due to the high price of edible bird's nest (products of swiftlet farming). As of 2017, there are around 60,000 swiftlet farming houses in Malaysia. However, due to inefficiency in the management system, a swiftlet farming house located near to the residential area had brought a lot of complaints. Although these complaints can be reduced through the management of the swiftlet farmers, yet there is no guarantee which will show that there will no problem produce by swiftlet farming houses. Therefore, this study aims to study the legislation regulating the swiftlet farming houses, as well as to identify the side effects of swiftlet farming houses on the local communities. The mixed methodology has been adopted throughout the research process which includes qualitative and quantitative approaches. Research findings were based on the data collected through interviews with several officers in local government, and questionnaires distributed to 100 residents in Bentong who are living within a radius of 150 meters from swiftlet farming houses. Data collected from questionnaires were analyzed by SPSS statistical analysis. Findings indicated that the swiftlet farming houses were regulated by the Street, Drainage and Building Act 1974 and Local Authority Act 1976. Nevertheless, the communities were affected both positively and negatively by the swiftlet farming house. The impact of swiftlet farming houses on local communities shown the need for adoption regulation been adopted on the swiftlet farming houses. In a nutshell, the legislation on swiftlet farming house is essential to confine the swiftlet farming house in order to ensure the
\end{abstract}


growth of this industry while taking care of the communities. Apparently, good regulations and good management can definitely avoid the side effects on the communities.

Keywords:

Communities, Impact, Regulation, Swiftlet Farming House

\section{Introduction}

Edible bird's nest (EBN) is one of the traditional medicines that are often used by Chinese. People believe that EBN is one of the powerful herbs to neutralize the poisons over the body and it contained source of food nutrient to maintain the skin health (Chua \& Zukefli, 2016). Besides, it is also one of the best medicines to help the new cells growth which are more active in the body, balance the energy and increase immunity, healthy lung and making one live longer. However, it is unaffordable by the low-income group, since EBN is selling between RM9,000 and RM10,000 per kilogram (processed) and those unprocessed EBN is selling at RM6,000 per kilogram (Wong, 2017).

As one of the most highly valued of the food products of South East Asia (Babji et al., 2015) trigger many Malaysians started their jobs as farmers, a swiftlet farmer. According to Lim (2007), swiftlet farming is not hard as the normal farmers; swiftlet house is easy to manage and doesn't need professional skills in farming. Other than that, swiftlet farming is also a business that can gain a decent profit within 3 years. According to Malaysia's Open Data Portal, swiftlet farming house in Malaysia soared from 6599 (year 2012) to 9732 in year 2014. Currently, there are more than 60,000 swiftlet houses in Malaysia by year 2017 (Wong, 2017), and figure 1 below presents the numbers of swiftlet farming house industry in Malaysia from year 2012 to 2014.

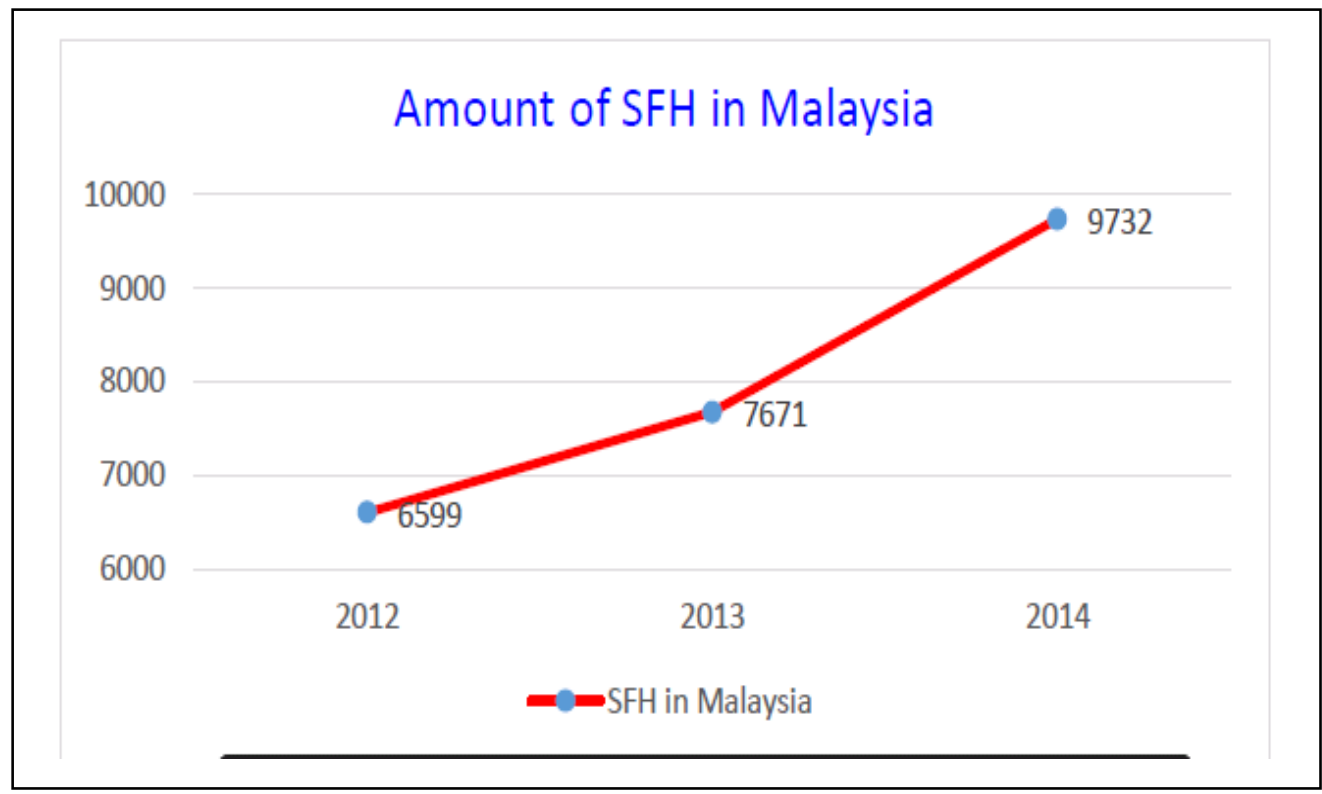

Figure 1.1: Below Shows the Growths of Swiftlet Farming House (SFH) Industry Source: (Malaysia's Open Data Portal, 2014)

Nevertheless, people claimed that swiftlet farming house was not follow the guidelines provided, surrounding of swiftlet farming house is dirty and the speaker installed was making 
noise pollution (Duckett, 2010). Swiftlet farming house had affected people stay around it by sound pollution, air pollution, hygienic problem, health problems and more.

EDB is able to provide health benefits, such as aiding digestion, raising libido, improving the voice, alleviating asthma and improving concentration (Babji et al., 2015), however inefficient management system of swiftlet farming house raises a lot of issues and complaints (Tan, 2009). Most of the complaints are regarding noise pollution (Duckett, 2010). Noise pollution happened due to recording of bird sound needed in order to attract swiftlet.

Although there is a swiftlet farming guideline provided by the Local Government, but there are many inconsiderate farmers who did not stick with the guidelines provided, they used to play the sound all day long which exceed $55 \mathrm{~dB}$. Furthermore, residents also complaints about hygiene and health problem, where swiftlet faeces are harmful to their health. Apparently, this industry is economically viable, but the negative impacts of the industry should not be set aside (Aref et al., 2010).

\section{Literature Review}

\section{Swiftlet and Swiftlet Farming}

Swiftlet is a kind of bird species that inhabit the cave from Apodidae family (Ibrahim et al, 2009). More specific, the scientific name of these bird species is Adreomus Fucihangus, and can live within 24 to 30 calsius degree (Mulia, 2008) Nesting usually occurs in caves, often in vast colonies. Buildings are sometimes also employed and owing to the financial rewards associated with this species (Ibrahim et al, 2011).

According to Merican (2007), swiftlet farming is defined as an industry that converts of peoplecentric buildings into buildings used to house and protect a certain species of swiftlets for the purposes of accommodating such swiftlet populations as well. The farmers get profit by selling the nests of swiftlet.

\section{Method to Attract Swiftlet}

Breeding of swiftlet is a difficult task as they are highly sensitive to human presence and require special care to produce high quality of bird nests (Othman et al., 2009).In addition, sudden changes in temperature and humidity can cause swiftlet to move elsewhere.

The swiftlet farming is similar to the bee farming, humans built a specially designed building that resembles the cave situation to providing nesting places to attract these swiftlets to make nests in the building (Lim, 2011). There are several methods may use to attract swiftlet, which is playing recording of swiftlet's sound and control thermal in the swiftlet farm.

\section{Recording of Swiftlet's Sound}

The most effective way to attract swiftlet is attracting them by using voice recording of swiftlet calls to stimulate and attract or influence to enter a specially constructed building for the purposes of this swiftlet farming (Lim, 2011). Swiftlets usually do not know the existence of new swiftlet farm unless they detect sound broadcasts installed via sound systems (Lim, 2009). Advances in technology show the use of speakers to call swiftlet (Kurniati \& Dolorosa, 2012).

On the other hand, there are a wide range of swiftlet sounds recording available in the market. The farmers are encouraged to play the bird's sound at a certain time only to avoids action taken against them in the event of default. At other times, the sound can just play in the swiftlet 
farming house only. This rule is stated in the guideline book and announced by the Ministry of Agriculture \& Agro-Based Industry Malaysia.

This swiftlet's voice recording can be classified into three types, which are the voice to attract the swiftlet coming to live in the swiftlet farming house, the voices of bird mating to accelerate the swiftlet population in the swiftlet farming house and the voice to maintain swiftlet staying in the swiftlet farming house (Budiman and Sallehuddin, 2005).

\section{Thermal Control in Swiftlet Farming House}

Designation of SFH needs to considered about external factor and internal factor. External factors mean the height and source of food and water that exist in the location of SFH. However, internal factors are the ambient temperature, average temperatures, air velocities, humidity and light intensity (Ibrahim et al., 2011). The comfort temperature for swiftlet is between 25 degrees Celsius and 30 degrees Celsius (Kuan and Lee, 2005).

According to Kuan and Lee (2005), if the temperature exceeds 30 degrees Celsius, the bird's saliva will dry up and cause a shrinking nest but if the temperature is too cold, which below 25 degree Celcius, the saliva will harden and hard to construct bird's nest. In addition, the light intensity factor also needs to be considered. Light intensity should be kept below 5 LUX. This means that light must be low in order to create a dull atmosphere like in a cave, a dark place is more secure to the new born birds (Ibrahim et al.,2011).

Bacause of the swiftlet requires a dark space for nesting, the nesting space is usually blocked and seperated into some small space. Lastly, relative humidity in the range of $80 \%$ and $90 \%$ is recommended to maximize the productivity of swiftlet nest. Higher relative humidity breeds fungus on nesting plank and dampness leads to stagnant water pools and lead to mosquito breeding not build their nest on fungus plank Therefore, humidifier should be provided to control the desirable range of relative humidity (Ibrahim et al.,2009).

\section{Swiftlet Farming House (SFH)}

Swiftlet farming house (SFH) is an industry or a building which it is focusing in farming the swiftlet for it to produce edible bird nest in certain quantity depends on the size of the farming house. The design and construction of the building might affect to the population of swiftlet (Ibrahim et al, 2009). According to Department of Veterinary Services Malaysia (2010) SFH can be categorized into two categories which are SFH in urban area and SFH in rural area.

\section{SFH in Urban Area}

SFH in urban area is referring to the SFH that built or exist in the city area which is usually a renovation of the shophouse to SFH. Construction of this SFH must not modify the appearance of the building and enlarge the building without permission (Garis Panduan Pembangunan Industri Burung Walit, 2010).

This type of SFH had more stringent requirements and its construction is more restricted as it necessary to follow the term and conditions as stated above. More, SFH in urban area needs to register with Department of Veterinary Services and apply a farming license from the local government.

\section{SFH in Rural Area}

This type of SFH refers to the SFH which built on privately-owned agricultural land or built in industrial area (Garis Panduan Pembangunan Industri Burung Walit, 2010). This type of SFH 
construction is more flexible according to the owner's wishes and abilities. Yet, the construction is required to comply with the requirements. For example, the height of the building is not more than or equal to 12 meters. In addition, owner of SFH in rural area needs to provide a buffer zone which at least 20 meters from residential area.

The construction materials used vary according to the needs of the farmers. Among the materials used for construction are bricks, zinc, concrete blocks, asbestos, clay and so on (Ibrahim et al., 2011). The farmers may choose the materials that help to reduce heat and suitable for SFH. However, there are unauthorized sites for the construction of SFH such as schools, health clinic, places of worship, playground areas, water catchment areas and permanent reserved forest.

\section{Ideal Structure of SFH}

The internal design of SFH will affect the yield of the nest in the SFH (Lim, 2011). According to Mardiastuti (1998), an SFH needs to have the same interior layout as the cave interior layout, which includes the foyer or spin space and space for nesting. Usually swiftlet will fly around in front of the cave before entering into its nest. Therefore, swiftlet house should be equipped with spaces for them to spinning around and spaces for them to make nests (Budiman and Sallehuddin, 2005).

\section{Legislation of SFH}

The swiftlet farming industry is governed by various guidelines drawn up by the Local Government as well as Department of Veterinary Services. Swiftlet farmers must sign up with Department of Veterinary Services and apply for premises license to the nearest local authority.

According to Section 107, Act 171, a license or permit, local council may fix fees for such license or permit and charge for inspect or supervise any trade, occupation or premises on which the license was granted in relation to premises building (Garis Panduan Pembangunan Industri Burung Walit, 2010). Table 1 shows Swiftlet Farming House is restricted by the acts or rules below:

Table 1: Restrictions Of Swiftlet Farming House

\begin{tabular}{|c|c|}
\hline Department / Authorities & Law Restrictions \\
\hline $\begin{array}{l}\text { Department of Veterinary } \\
\text { Services }\end{array}$ & $\begin{array}{l}\text { - Animals Act } 1953 \text { (Revised-2006) [Act 647] } \\
\text { - Veterinary Surgeons Act 1974 [Act 147] } \\
\text { - Feed Act 2009 [Act 698] } \\
\text { - MS 2027:2006, Amalan Baik Penternakan } \\
\text { Haiwan (GAHP) } \\
\text { - MS 2273:2009, Good Animal Husbandry } \\
\text { Practice - Edible-Birdnest Swiftlet Ranching } \\
\text { and Its Premises } \\
\text { - MS 2333:2010 (P) - Good Manufacturing } \\
\text { Practices (GMP) for Processing Raw-Clean } \\
\text { and Raw-Unclean EBN } \\
\text { - MS 2334:2010 (P) - Edible-Birdnest (EBN) - } \\
\text { Specification } \\
\text { - Sijil Amalan Ladang Ternakan 2003 (SALT) } \\
\text { - Veterinary Health Mark (VHM) }\end{array}$ \\
\hline
\end{tabular}




\begin{tabular}{|c|c|}
\hline $\begin{array}{l}\text { Ministry of Housing and Local } \\
\text { Government }\end{array}$ & $\begin{array}{l}\text { - Town and Country Planning Act } 1976 \text { [Act } \\
\text { 172] : Subsection } 19 \text { (1) and Section } 22 \text { (A) for } \\
\text { planning permission requirements. } \\
\text { - Local Government Act } 1976 \text { [Act 171] : } \\
\text { Section } 107 \text { and } 110 \text { for the purpose of } \\
\text { licensing and enforcement } \\
\text { - Street, Drainage and Building Act } 1974 \text { [Act } \\
\text { 133] : Section } 70 \text { for building plan application } \\
\text { requirements. } \\
\text { - Uniform Building Bylaws } 1984 \text { which is } \\
\text { adopted by the Local Authority for matters } \\
\text { involving renovations of existing buildings for } \\
\text { the purpose of swiftlet farming house. } \\
\text { - The Trades, Business and Industrial Laws } \\
\text { adopted by Local Authorities for enforcement. }\end{array}$ \\
\hline Ministry of Health & $\begin{array}{l}\text { - Food Act } 1983 \text { [Act 281] } \\
\text { - Food Regulations } 1985 \text { [P.U.(A)437] } \\
\text { - Food Hygiene Regulation } 2009\end{array}$ \\
\hline $\begin{array}{l}\text { Department of National } \\
\text { Heritage }\end{array}$ & - National Heritage Act 2005 [Act 645] \\
\hline
\end{tabular}

Source: (Department of Veterinary Services Malaysia, 2010)

\section{Local Communities}

Hillery (1955) defined community as people in social and cultural interaction within geographic area and having one or more additional common ties. The definition of community in specific geographic meaning is defines as a spatial boundary and area and also refers to groups of people with a common interest (Chapman \& Kirk, 2001). However, Smyth (2009) defined community as a set of people living together, symbiotically bound to each other and their habitat, thereby rendering themselves a distinct collective personality.

Aref et al. (2010) defined community as a group of individuals living or working within the same geographic area with some shared cultures or common interests. While, Mills (2005) giving the definition of community as it involves people, who stay in a specific geographical area, live their life, earn their living, raise their family, share common cultural values and norms, have a sense of belonging for their fellow members and try to satisfy their social, economic, political and psychological needs.

\section{Impact of SFH on Local Communities}

Although the SFH industry is economically viable, but the negative impacts of the industry should not be set aside (Chin, 2011).

\section{Positive Impact}

Positive impact is an effect that benefits to an organization or a community. In this research, positive impact refers to the benefits brought by swiftlet farming house. Positive impact of swiftlet farming house such as below:

\section{Property Value}

Swiftlet farming house is a kind of business that involved small capital investment and could generate enormous return in future (Ibrahim et al., 2009). Therefore, investors of this 
investment keep increasing. The existence of swiftlet farming house on a land will affect the value of land sale because of the location has established swiftlet farming house, the location will be lured by other investors and directly increase the land value of the land (Kurniati and Dolorosa, 2012). According to Zhang, property in Jerantut had increased $1000 \%$ in the past ten years due to flourish of swiftlet farming in Jerantut (2017).

\section{Economic}

According to EPP 2: Edible Bird's Nest Swiftlet Farming (2015), Edible Bird's Nest Swiftlet Farming is the second of ETP, 145 tonnes of edible bird's nest products were exported in 2014 and Government Malaysia believes that gross national income (GNI) of this industry will be RM4541.2 Million by year 2020 (2015). Other than that, fees that pay for applying permit and license are also an income of local authorities. The average operation license fee is RM150 per year per swiftlet farming house (Othman et al, 2009).

\section{Negative Impact}

Negative impact refers to a fact, situation, or experience that is negative is unpleasant, depressing, or harmful (Abdulahi et al., 2014). The followings are the negative impacts of swiftlet farming house on local communities.

\section{Noise Pollution}

The sound system installed to attract swiftlets creates noise pollution problems that disturb the surrounding residents and tourists (Duckett, 2010). Noise pollution is harmful to health and the environment (Chin, 2011). According to him, the loudspeaker system usually has been installed for quite some time and this has led to complaints from residents around this noise pollution. There are in some cases residents leave the building and move elsewhere because they can not withstand such an environment (Chin, 2011). There was an inconsiderate swiftlet farming house owner by installing an external sound funnel directed to the residents' dwelling with a high ambiguity in the long term (Lim, 2011). This has caused complaints from residents about this noise pollution which disturbed their peace. The usual sound volume that played by the farmers to attract swiftlets is around $45 \mathrm{~dB}-55 \mathrm{~dB}$. However, there are some inconsiderate farmers played at larger volume which more than $55 \mathrm{~dB}$ to attract swiftlet, they think that the larger sound, more attractive to swiftlet (Hafiz et al., 2012).

\section{Air Pollution}

Swiftlet farming house leads to the problem of unpleasant odors as a result of faeces and dirt made by swiftlets (Kurniati et al., 2012). According to Kuniarti \& Dolorosa (2012), air quality in the swiftlet farming house area is also disturbed. There are complaints of local residents about the irresponsible farmers who deliberately, they did not manage to clean the bird drops and dirt made by swiftlet (Roselan, 2016).

\section{Health Potential Disease}

As Nash (2006) has put it, "the material qualities of a specific landscape are critical to the production of certain diseases: local habitats that support anopheles' mosquitoes, warm temperatures that allow the survival of parasites and bacteria, the material and biological conditions of human communities. These conditions have all been linked to urban swiftlet farms in Malaysia (Connolly, 2016). Therefore, SFH is potential to bring the following disease such as Cryptococcus, Avian Influenza, Dengue Fever, and Lung and Respiratory Disease. 


\section{City Appearance}

For swiftlet farming purpose, structure of the building should be designed in a special way in which only holes will be walled (Sulaiman et al, 2012). Besides that, the bird's faeces around the swiftlet farming house area are unmanageable, caused the area becomes dirty and causing health problems (Chin, 2011).

\section{Safety Aspect}

According to Pan (2018), chairman of the Malaysian Bird's Nest Merchants Association claimed that the rise in the price of edible bird nest attracted thieves, those thieves not only affecting the livelihood of the swiftlet farmers, but also destroying the swiftlet's residence and causing the death of swiftlet, leaving swiftlet to face the crisis. Valuable birds' nest could trigger an increase in criminal activities in towns or industrial areas where swiftlet farming is allowed (Pan, 2018)

\section{Mental health and Quality of Life}

Mental health and quality of living refers to those aspects of swiftlet farming which do not directly impact human health or cause tangible forms of disease. In fact, for many people living or working in the vicinity of swiftlet farms, the presence of large numbers of swiftlets living in close proximity to humans was 'offensive the senses' (Connolly, 2016). Those negative impacts such as noise pollution, air pollution and fear of potential disease from swiftlet farming house might affect mental health and quality of living of the residents stay near to swiftlet farming house.

\section{Research Methodology}

In this study, a mixed method research strategy has been adopted along the research process. The results from this research were based on the interview conducted with an officer of local authorities in Bentong District, Pahang, and Departments of Veterinary Services. In addition, questionnaires were distributed to 100 residents in the case study area within radius of 150 meters from swiftlet farming house in order to get the impacts of swiftlet farming house on the local communities. Besides of interview and questionnaire, observation method was also undertaken to observe the surrounding of swiftlet farming house such as the faeces of swiftlet and the volume of noise. The collected data were then analysed using SPSS.

\section{Case Study Area}

This study was conducted in Bentong District, Pahang, Malaysia. Bentong District area covers an area of 1,831 km² (Department of Statistic Pahang, 2018). Located north-east of Kuala Lumpur and Bentong District is near to Kuala Lumpur, it is located $80 \mathrm{~km}$ northeast of Kuala Lumpur and is opposite of the Titiwangsa Range. This district borders the State of Selangor to the west and Negeri Sembilan to the south. Bentong has popular areas such as Genting Highland and Bukit Tinggi. The history of Bentong's name is "Banyak Untung" which means prosperity because in the past, Bentong had tin mines. The Bentong District population is 114,397 according to the census in 2013, this information is quoted from the Department of Pahang State Statistics Department located in Bentong City. The location map of case study area was shown in Figure 1 below. 


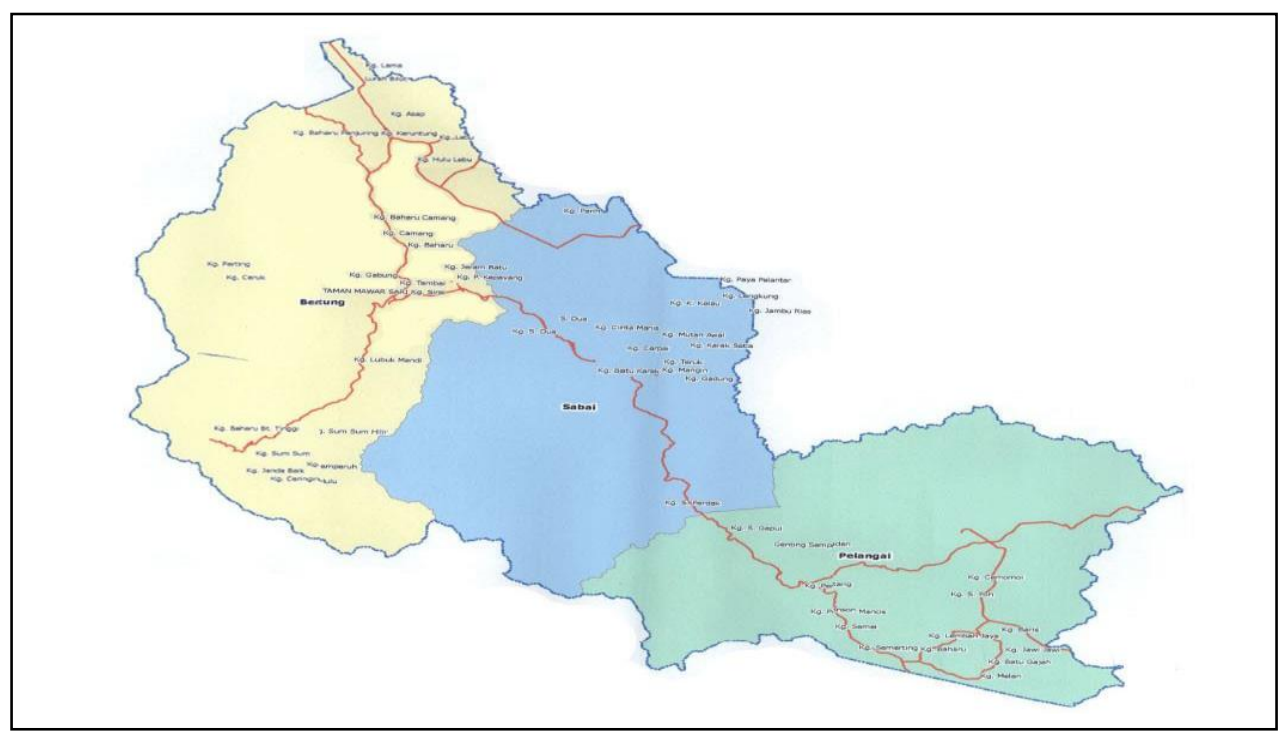

Figure 1: Location Map of Bentong, Pahang

\section{Results And Discussion}

\section{Respondent Profile}

Table 2 summarizes the respondents' profile according to the percentage of the overall number of respondents.

Table 2: Profile of the Respondents

\begin{tabular}{l|c|c}
\hline \multicolumn{1}{c|}{ Demographic } & Frequency & Percentage (\%) \\
\hline Gender: & 42 & 42 \\
Male & 58 & 58 \\
Female & & \\
\hline Age: & 17 & 17 \\
Below 19 Years old & 18 & 18 \\
20 to 35 Years old & 33 & 33 \\
36 to 55 Years old & 32 & 32 \\
Above 56 Years old & & \\
\hline Race: & 33 & 33 \\
Malay & 59 & 59 \\
Chinese & 8 & 8 \\
Indian & 0 & 0 \\
Others & & 20 \\
\hline Occupation: & 20 & 20 \\
Self-employed & 20 & 44 \\
Employee & 44 & 16 \\
Unemployed/Retired & 16 & 22 \\
Student & & 51 \\
\hline Level of Education: & 22 & 18 \\
Primary School & 51 & 9 \\
Secondary School & 18 & \\
STPM / Diploma & 9 & \\
Degree & & \\
\hline
\end{tabular}




\section{Acknowledgement About Swiftlet Farming House (SFH)}

Majority of the respondents are aware of the existence of SFH in the area, which as much as $96 \%$ of respondents. While only $4 \%$ of respondents did not know the existence of SFH in the area. From the result, it was found that majority of the respondents which as much as $63 \%$ were noticed the SFH through noise generated by SFH. Followed by $32 \%$ of them acknowledge through the appearance of the SFH. Figure 2 shows the ways of the respondents aware of the existence of SFH in the study area.

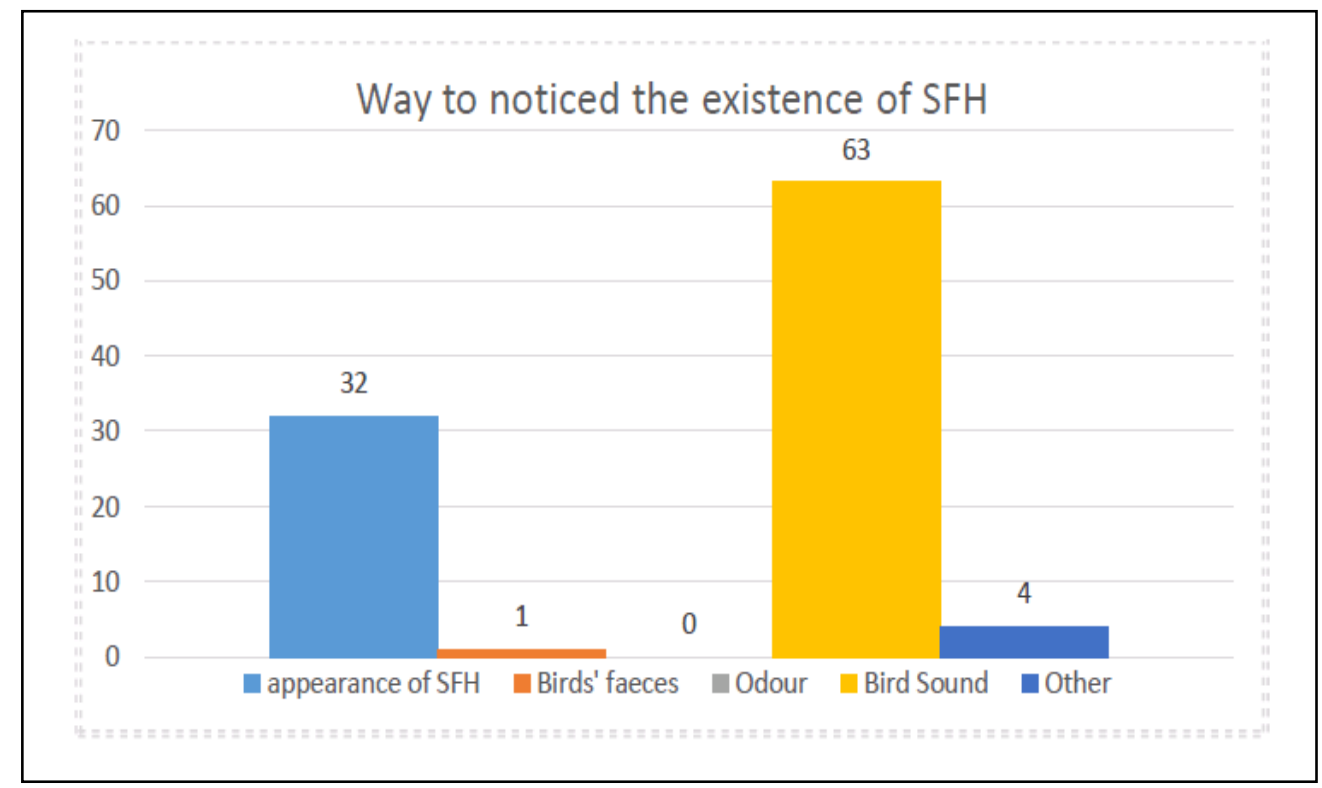

Figure 2: Ways of the Respondents Aware of the Existence of SFH

\section{Legislation and Regulation for Swiftlet Farming House (SFH)}

The findings from the interview undertaken with the officers of Bentong Municipal Council (MPB) shows that the SFH in Bentong are regulated by the Street, Drainage and Building Act 1974 (Act 133) and Local Authority Act 1976 (Act 171). In addition, currently, the SFH in the study area also regulated by the guidelines issued by Pahang State Government.Yet, the enactment of these regulations as 'guidelines' and not laws created a situation of legal ambiguity (Kuyucu, 2014). However, from interview, MPB is also proposed to have guidelines for controlling the SFH in Bentong in the future which is more emphasis than the current guidance.

On the other hand, from the interview it also revealed that limited enforcement action has been carried out on illegal swiftlet farms in Malaysian cities (Connolly, 2016). It was found that the guidelines and legal acts used by MPB on the SFH were an effective way to confine SFH in Bentong. However, the most challenges task need to be done by MPB is to convince all of the swiftlet farmers to register with MPB, for easier monitoring and confining efficiency. Bentong Municipal Council (MPB) is given power for the purpose of licensing and enforcement. Local council may fix fees for such license or permit and charge for inspect or supervise any trade, occupation or premises on which the license was granted in relation to premises building. Apparently, comply with legislation that regulated for SFH by MPB can helps to reduce negative impacts to the local communities. 


\section{Impact of Swiftlet Farming House (SFH) On the Local Communities}

From results, it was found that there were negative and positive impacts of SFH on the local communities in the study area. Generally, the SFH industry is economically viable, but the negative impacts of the industry should not be set aside (Chin, 2011). From the five listed of negative side effects, only two major impacts on the communities in the study area which are noise pollution and disturbance of the city appearance while other effects like air pollution, health potential diseases and security issue are less likely to be affected by the communities. The majority of respondents agreed that SFH produced problem of noise pollution and made disturbance on the city appearance. And the noise pollution was comes from was due to the swiftlet tweeters which is the sound system installed on SFH premises to attract swiftlets.

In regards to disturbance city appearance, SFH has also changed the appearance of the building by disruption to the scenery for them in terms of changing the shape of the building. The farmers used to enlarged or extend the building area to fit more swiftlets. Besides, swiftlets love the dark areas with little light like inside the cave. Therefore, the farmers will change the look of the building by closing all of the windows and doors in order to make the dark atmosphere.

According to Duckett (2010) and Chin (2011), the severe side effect of SFH is noise pollution. Clearly, it was found that there are negative impacts of the SFH on the local communities, but it can be control and reduced if the SFH comply with the guidelines provided by MPB. Figure 3 shows an analysis to determine the respondents' views of the presence of negative impacts of $\mathrm{SFH}$ on local communities in this area.

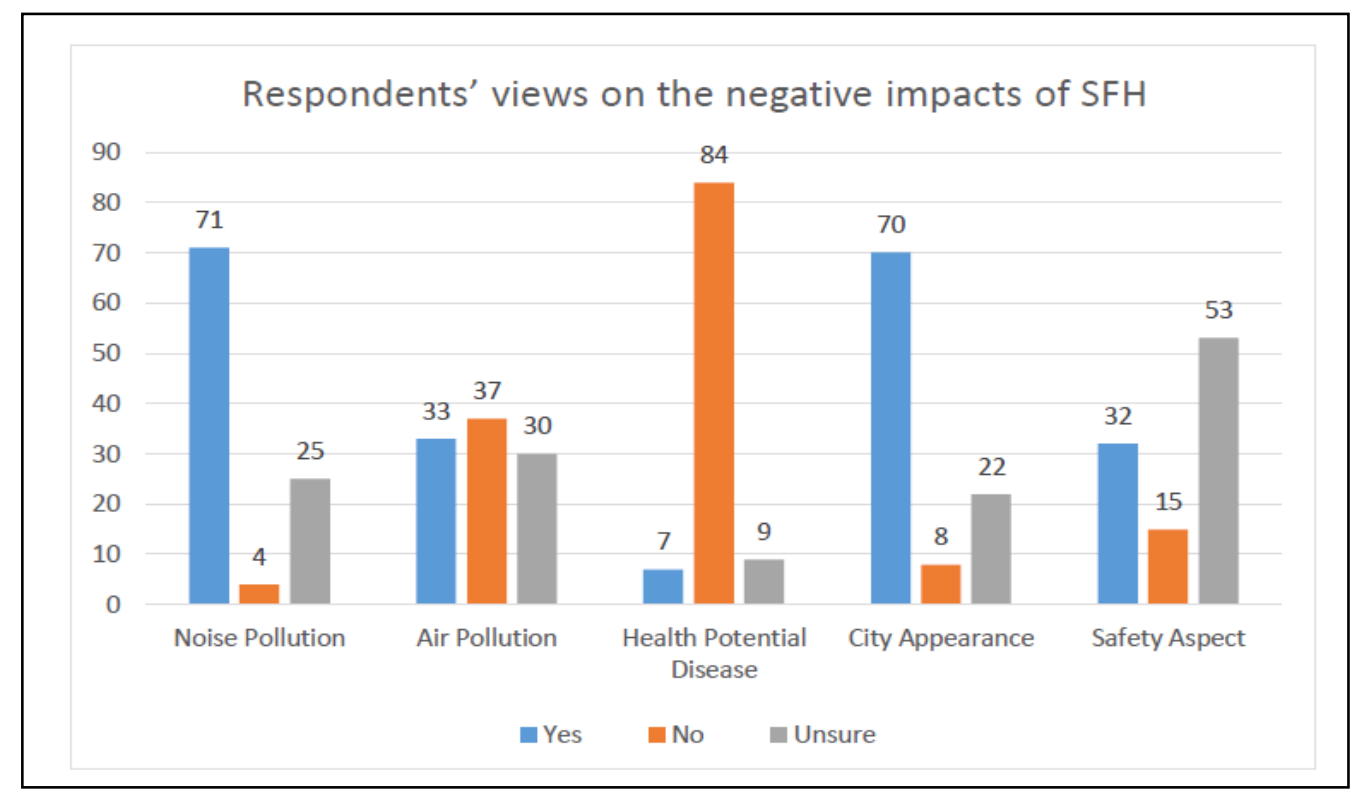

Figure 3: The Negative Impacts of SFH

On the other hand, there are two positive impacts that have been identified which are promotes local economic and increase the property value. Majority respondents agreed that the property value of the premise modified for SFH is increased significantly, with average increase of RM200 000. in fact, an article had reported that the value of shop lot in Jerantut Pahang had increased 1000\% in 10 years due to the evolution of swiftlet farming industry (Zhang, 2017). On the other hand, majority of the respondents were agreed the SFH also promotes the local economic in the case study area. In addition, an interview session undertaken with an officer Copyright (C) GLOBAL ACADEMIC EXCELLENCE (M) SDN BHD - All rights reserved 
of MPB revealed that the swiftlet farmer is required to pay for the swiftlet farming license yearly, and subsequently this amount of license fees can help to improve infrastructure of the district and promotes local economic.

\section{Conclusion}

Recently, swiftlet farming industry is on an uptrend mode and becoming more popular in Malaysia. It is believing that Gross National Income (GNI) of swiftlet industry will be increased by year 2020. Since the motivation of investors to invest in this industry are getting more and more, it is very important for the investors and public to get knowledge on the legislation that regulating SFH and to identify the side effects of SFH on the local communities. This research has revealed that SFH is under Local Authority responsibilities, and regulated by different guidelines such as the Street, Drainage and Building Act 1974 (Act 133) and Local Authority Act 1976 (Act 171). The legislation on SFH is essential to confine the SFH in order to ensure the growth of this industry while taking care of the communities. The research also identified that the communities in the study area are suffered from the side effects that generated by SFH such as noise pollution and health potential diseases. Apparently, these effects can definitely avoid if the SFH comply with the legislation. In a nutshell, good regulations and good management can definitely avoid the side effects on the communities and enhance an economic value of swiftlet farming industry.

\section{Acknowledgements}

We are grateful for the UTHM, particularly to the Human Resources Development Unit for the publication opportunity.

\section{References}

Aref, F., Gill, S.S., \& Aref, F. (2010). Tourism Development in Local Communities: As a Community Development Approach. Journal of American Science, 6(2). Retrieved from http://www.americanscience.org

Abdulahi, A., Samadi, B. \& Gharleghi, B. (2014). A Study on the Negative Effects of Social Networking Sites Such as Facebook among Asia Pacific University Scholars in Malaysia. International Journal of Business and Social Science. 5. 133-145.

Babji, A.S., Nurfatin, M.H., Etty Syarmila, I.K. \& Masitah, M. (2015). Secrets of edible bird nest. UTAR Agriculture Science Journal, 1 (2015), pp. 32-37.

Budiman,A \& Ibrahim,M. S. (2005). Penghasilan dan Pemasaran Sarang Burung Kuala Lumpur, Malaysia. S.A Majeed \& Co Sdn Bhd.

Chapman, M., \& Kirk, K. (2001). Lessons for Community Capacity Building: A summary of the research evidence. Retrieved 2, October, 2018, from http://www.scothomes.gov.uk/pdfs/pubs/260.pdf

Chin S. L., (2011). Preserving George Town's UNESCO World Heritage Shophouses - An Eco friendly Alternative Shophouses Prototype for Swiftlet's Farming and Research. Retrieved from http://www.tanggam.com.

Chua, L. S. \& Zukefli, S. N., (2016). A comprehensive review of edible bird nests and swiftlet farming. Journal of Integrative Medicine. Vol. 14 (6), pp.415-428.

Connolly, C. P. (2016). A landscape political ecology of "swiftlet farming" in malaysian cities. $P Q D T \quad U K \quad \& \quad$ Ireland. Retrieved from http://libproxy.library.wmich.edu/login?url=https://search.proquest.com/docview/183 7035483 ?accountid=15099\%0Ahttp://primopmtna01.hosted.exlibrisgroup.com/openurl/01WMU/01WMU_SERVICES??url_ver= Z39.88-2004\&rft_val_fmt=info:ofi/fmt:kev:mtx:dissertation\&genr

Department of Statistics Pahang, (2013), Population of Bentong District, Bentong Branch 
Department of Veterinary Services Malaysia, (2010), Garis Panduan Pembangunan Burung Walit (1GP)

Duckett,R. (2010). Urgent action needed against Penang swiftlet farming - Aliran. Retrieved from https://aliran.com/civil-society-voices/urgent-action-needed-against-for-penang-

EPP 2: Edible Bird's Nest Swiftlet Farming. (2015). Retrieved May 15, 2018, from http://etp.pemandu.gov.my/Agriculture-@-Agriculture_-_EPP_2Edible_Bird's_Nest_Swiftlet_Farming.asp

Ibrahim S.H, W.C., T., \& Baharun, A. (2009). A study on suitable habitat for swiftlet farming. Universiti Malaysia Sarawak (UNIMAS), Sarawak.

Hafiz, M., Suriaty, R., Mastura, S., \& Salleh, I. (2012). Observation on swiftlet nesting behaviour as influenced by, (April).

Hillery, G. (1955) Definitions of Community: Areas of Agreement. Rural Sociology, 20, 111123.

Ibrahim S.H, Baharun, A., \& Kabiru, A. (2011) Study on Suitable Habitat for Swiftlet Farming Using Energy Plus, Universiti Malaysia Sarawak (UNIMAS), Sarawak.

Kuan, H., \& Lee, J. (2007). The complete introductory guide to swiftlet farming. Struan Inc. Retrieved from http://ent.library.utm.my/client/en_AU/main/search/detailnonmodal/ent:\$002f\$002fS D_ILS\$002f0\$002fSD_ILS:295645/ada?qu=Malaysia+-+ Economic + aspects $\&$ ic $=$ true $\& p s=300$

Kurniati, D. \& Dolorosa, E., (2012). Analisis Faktor Internal dan Eksternal Usaha Agribisnis Sarang Burung di Kota Pontianak. Jurnal Universiti Tanjungpura).

Kuyucu, T., (2014). Law, Property and Ambiguity: The Uses and Abuses of Legal Ambiguity in Remaking Istanbul's Informal Settlements. International Journal of Urban and Regional Research, 38(2), pp.609-627.

Lim, C. (2007). Make millions from swiftlet farming: a definitive guide. True Wealth. Retrieved from https://books.google.com.my/books?id=Ip9tNwAACAAJ\&dq=swiftlet+million\&hl=e n\&sa=X\&ved=0ahUKEwi55O2Eu4fbAhVEuI8KHb_vBOsQ6AEIMTAB

Lim, C. K. (2011). Opportunity and Sustainability of Swiftlet Farming in Malaysia. Universiti Malaysia Sarawak. Seminar paper of International Conference of Swiftlet Farming (ICOTOS). Lim, C. K. (2011). Opportunity and Sustainability of Swiftlet Farming in Malaysia. Universiti Malaysia Sarawak. Seminar paper of International Conference of Swiftlet Farming (ICOTOS).

Merican, S. \& Hameed, E., (2007). The 2007 Malaysian Swiftlet Farming Industry Report (Summary and Synopsis (Publication Date: 1st June 2007)

Mills, R. C. (2005). Sustainable community change: A new paradigm for leadership in community revitalization efforts. National Civic Review, 94, 9- 16.

Mulia, A. H. (2008) Strategi Jitu Memikat Walet: AgroMedia.

Othman, A.K., Abidin, W. A. W. Z., Lee, K. M., Zen, H., Zulcaffle, T. M. A., \& Kipli, K. (2009). Wireless Sensor Networks for Swiftlet Farms Monitoring, 3.

Pan, Z.Z. (2018). Farmers asked heavy law and punishes edible bird nest thief. Retrieved May 31, 2018, from http://www.enanyang.my/news/

Roselan, A.M. (2016). Batal lesen burung walit jika ingkar | Timur | Berita Harian. Berita Harian. Retrieved from https://www.bharian.com.my/node/159990

Sulaiman, S. S., Yahaya, N., \& Khalid, R. M. (2012). Heritage tourism management in the World Heritage Sites, Malaysia: Legal and planning issues. Retrieved from https://uitm.pure.elsevier.com/en/publications/heritage-tourism-management-intheworld-heritage-sites-malaysia-1 
Tan, J. (2009). Tighten rules on swiftlet farms. Retrieved from http://www.thesundaily.my/node/160030

Wong, J. (2017). Bird's nest prices soar after China lifts import ban - Business News | The Star Online. Retrieved from https://www.thestar.com.my/business/businessnews/2017/12/18/birds-nest-prices-soar-after-china-lifts-import-ban/

Zhang, Y. P. (2017). 10 Times in 10 years, swiftlet farming increased the value of Jerantut land. Nan Yang. Retrieved from http://www.enanyang.my/news/20171206/10 